\title{
Should Forensic Accounting Be Included in Curricula of Accounting Departments: the Case of Saudi Arabia
}

\author{
Dr. Elzain Omer Elzain ${ }^{1}$ \\ ${ }^{1} \mathrm{CBE}$, Department of Accounting, College of Business and Economics, Qassim University, Saudi Arabia \\ Correspondence: CBE, Department of Accounting, College of Business and Economics, Qassim University, P.O. Box: \\ 6640, Buraidah-51452, Saudi Arabia.
}

Received: March 14, 2021

Accepted: March 27, 2021

Online Published: March 30, 2021

doi:10.5430/ijhe.v10n4p258

URL: https://doi.org/10.5430/ijhe.v10n4p258

\begin{abstract}
The objective of this research paper is to define the significance of forensic accounting and reflecting the need of including forensic accounting in the curricula of accounting departments in universities in the Kingdom of Saudi Arabia. The research followed the descriptive analytical approach. The research community consisted of a sample representative of faculty members in the accounting departments of universities in the Kingdom. Where (150) questionnaires were distributed and (126) questionnaires were collected, i.e., a response rate of (84\%). The research employed the (SPSS) program to analyze and test its hypotheses, such as "There is no knowledge of the importance of forensic accounting among accounting department staff of Kingdom of Saudi Arabia universities". The research has reached several results, the most important of which are: all faculty members in accounting departments at universities in the Kingdom are aware of the significance of forensic accounting, and they agreed that it should be included in the accounting education curriculum. Finally, the research calls for numerous recommendations, the most important of which are: setting specific and clear plans for how to include forensic accounting in the accounting curricula in accounting departments in universities in the Kingdom, and organizing more (conferences, researches, training courses, workshops...) by accounting departments in universities in the Kingdom and other bodies that regulate the profession of accounting in the field of forensic accounting to further demonstrate its real significance.
\end{abstract}

Keywords: forensic accounting, accounting departments in Saudi universities

\section{Introduction}

The global financial crisis that swept the world in (2008 AD) resulted in huge losses; the investors have borne the largest part of these losses. This made the professional bodies of specialists, among them the accounting bodies, looking for the causes of the problem and its financial, economic and social implications and searching for appropriate solutions to it. In this context, the researchers found that one of the most appropriate means to reduce financial and administrative corruption is forensic accounting as it is a comprehensive tool for investigating and verifying financial issues, due to it works to settle the financial disputes using laws and legislation (Bourgl, 2015).

Forensic accounting has been defined as the science that deals with the application of knowledge in the fields of accounting, finance, taxation, and auditing in order for analysis, investigation and inquiry, examination and testing of issues in civil and criminal law, in an attempt to reach the honesty through which the forensic accountant is able to provide his expert opinion, (Singleton \& Singlton, 2010). The American Institute of Certified Public Accountants also defined forensic accounting as: Accounting that involves the application of special skills in accounting, auditing, financial affairs, quantitative methods, or parts of law, research and investigative skills to collect, analyze and evaluate evidentiary items and interpret results and report on them (AICPA, 2005).

In developed countries, great strides have been made in organizing and teaching the field of forensic accounting. In the United States of America, for example, several professional organizations such as the Association of Certified Fraud Specialists and the Association of Certified Fraud Examiners grant certificates that entitle the professional to be a forensic accountant, after completing several requirements that include acquiring various skills and sciences. There are also a large number of American universities that offer educational programs in forensic accounting; as one study indicated that 21 colleges and universities in the United States offer various semesters in criminal accounting, and that the American Public Company Accounting Oversight Board will issue its instructions to the legal accounting firms that they must have an integrated team of forensic accountants (Cumber 2014). 
The number of public universities in the Kingdom of Saudi Arabia has reached (33) and the number of private universities and colleges has reached (35). Most of these universities have colleges concerned with the study of finance and business and contain departments that study the major of accounting. (www.moe.gov.sa).

From the foregoing, it is clear that there is a need to shed light on the field of forensic accounting so that there is a wider interest from the specialists and researchers, as well as from the universities and colleges of accounting in developing curricula and adopting the professional programs, as well as from the Saudi Organization for Certified Public Accountants in overseeing legal accounting firms, in addition, including professional fellowship tests for the subjects of the forensic accounting, (https://www.alwatan.com.sa/article/37767).

\section{Research Problem}

There is a great role for the forensic accountability in preventing, detecting fraud and financial crimes of all kinds, and helping to support its prosecution. In addition, it has a great role to settle conflicts, settle financial disputes between the company and any other parties, and carry out internal investigations. Therefore, the problem of this research is to identify the extent to which accounting departments at universities in the Kingdom of Saudi Arabia need to include forensic accounting in its curricula. Accordingly, the research problem can be formulated in the following questions:

1) What is the extent to which members of the faculty in the accounting departments of universities in Saudi Arabia are aware of the importance of the forensic accounting?

2) To what extent are the faculty members in the accounting departments of universities in the Kingdom of Saudi Arabia aware of the need to include the forensic accounting in the accounting education curricula?

3) What are the difficulties that face faculty members in accounting departments at the universities in the Kingdom of Saudi Arabia and prevent them from including the forensic accounting in the accounting education curricula?

\subsection{Research Objectives}

The study has the following objectives:

1) Determine the extent to which staff members of accounting departments in Kingdom of Saudi Arabia universities are aware of the importance of forensic accounting.

2) Measure the extent of awareness of teaching staff of Kingdom of Saudi Arabia universities departments of accounting of the necessity of inclusion of forensic accounting in curriculum.

3) Determine constraints faced by Kingdom of Saudi Arabia universities staff of accounting departments preventing the inclusion of forensic accounting in the curricula.

\subsection{Research Importance}

The study is important because it could help add a new subject to meet society's need. It adds also to Kingdom of Saudi Arabia small number of forensic accounting studies.

\subsection{Research Hypotheses}

The study tested the following hypotheses:

$\boldsymbol{H}_{1}$ : There is no knowledge of the importance of forensic accounting among accounting department staff of Kingdom of Saudi Arabia universities.

$\boldsymbol{H}_{2}$ : There is no need among staff members of Kingdom of Saudi Arabia universities accounting department staff for the inclusion of forensic accounting in accounting teaching curriculum.

H3: There are no constraints from academic staff perspective of the department of accounting in Kingdom of Saudi Arabia universities preventing the inclusion of forensic accounting in the curriculum.

\subsection{Research Previous}

Curtis (2008): The study sought to prove the need to incorporate criminology, legal and organizational environment and ethics in the forensic accounting curriculum and how these could be incorporated. Topics included the effect criminology on the legal environment, and the legal topics for a forensic accounting curriculum such as fraud, financial crimes, information collection, and privacy, interviews, professional and organizational procedures, legal procedures, evidence and ethical standards which the accountant must be obliged to follow.

Wadhwa and Pal (2012): This study aimed at knowing the different uses of the forensic accounting in addition to identifying the role of forensic accounting techniques in detecting fraud operations in India. Secondary data and 
interviews were used with the prominent figures in the corporate sector.

It reached many results, including: the forensic accounting has recently been highlighted in India due to the rapid increase in fraud and money laundering crimes and the belief that the legal authorities do not have the expertise and time necessary to detect the financial fraud.

The study also recommended many recommendations, including: The necessity for private companies to adopt the works of the forensic accounting profession, in addition to providing specialized training from the reality of the practical life.

Alsaad (2012): The studied forensic accounting so as to understand its importance and role in legal cases. A questionnaire was designed with a number of axes and filled by a random sample of academics. certified accountants in Saudi Arabia. The most important findings were that forensic accounting seek to satisfy the needs by the judiciary for financial experts who can testify in financial disputes. It draws its importance from it satisfaction of courts need for accountants specialized and fully knowledgeable of the forensic and legal aspects of financial disputes in addition to their knowledge of accounting aspects. There are constraints in the face of teaching and practice of legal in the future such as the lack of qualified cadres both scientifically and in practice because departments of accounting in universities were not interested in graduating qualified graduates in this field. He recommended that more attention be paid to this area for its importance and because the demand for their services will increase in the future.

Gamber (2014): The study sought to understand the importance of forensic accounting and the need to incorporate it in high education curriculum in Libyan universities accounting departments. The study discussed a number of hypotheses: that there a lack of awareness of the importance of forensic accounting among the staff off accounting department of Libyan universities staff. The sample population was composed of all the members of staff of departments of accounting in Libyan universities. The study reached a number of findings of which was that there awareness exist of the importance of forensic accounting among Libyan staff of accounting departments in (Tripoli, Al Zawya, Al Giriyan). Among the recommendations was the need to strengthen awareness of the importance of forensic accounting among accounting staff of Libyan universities, and the advantages of its use in business through conferences, scientific seminars and by the encouragement of scientific and practical research in this area.

Mohammad (2017): The study aimed was to find the feasibility of inclusion of forensic accounting in the curriculum of Sudanese universities departments of accounting. The study followed the descriptive analytic method. Around 40 questionnaire were distributed to the sample population, Data was analyzed with SPSS. The results were the need to include topics in the curriculum of the departments of accounting in Sudanese universities to fulfill the requirements and provide the skills needed by forensic accountants. There were numerous other recommendations of which was the need to raise certified accountants ability to practice forensic accounting.

Mohammad Nur (2018): The objective of the study was to explain the role of forensic accounting in control of financial corruption in the financial reports of companies. The study followed the descriptive analytic method and tested hypotheses that there is no statistically significant differences between the awareness of academics, auditors and accountants. The hypothesis sought to determine the impact of application of forensic accounting to the control of financial and administrative corruption. The study reached a number of conclusions of which there is no impact for the use of forensic accounting in Sudan and that forensic accounting is not an accredited subject taught in Sudanese universities as a major course due to the lack of understanding of its significance in the control of financial and administrative corruption. Among the study numerous recommendations was the importance of inclusion of forensic accounting in universities educational programs so as to contribute to the control of administrative and financial corruption. It also recommended the need to resort the services of forensic accountant to enlighten the judiciary of the financial and accounting aspects of forensic accountant in a dignified scientific and practical style through which a fair and proper settlement for a dispute could be reached in such a manner as to satisfy all parties.

Mustafa \& Al-Harkan (2019): This study aimed to assess the adequacy of the current content of Forensic accounting in the accounting programs of Saudi universities, A field study was done conducted on the faculties of business and administration in Saudi universities, A set of results was reached: Forensic Accounting is not covered in the Accounting programs of Saudi Universities with a mean (1.99), There are facilities to teach Forensic accounting in Saudi universities but insufficiently with a mean (2.48), and the need to teach the Forensic accounting for undergraduate students to achieve competitive advantage in the job market with a high mean (3.76). Based on the previous results, the researchers presented a number of recommendations, including: The need to teach Forensic Accounting in business schools in Saudi universities so that graduates receive a competitive advantage in the market, The need to Include the Examinations of SOCPA (Saudi Association of certificated Public Accountants) with Subjects of Forensic Accounting, The need to provide the necessary facilities for colleges to teach Forensic 
accounting by providing good books covering subjects of Forensic Accounting And to attract faculty members and qualified experts with required quality.

Elzain (2019): The study sought to determine the extent to which Sudanese university accounting departments staff are aware of the importance of forensic accounting. The study adopted the descriptive analytic method with a representative sample selected from the academic staff of accounting departments in Sudanese universities. On average 48 questionnaire were distributed and filled up and all were collected with (100\%) response rate. The study relied on SPSS to test its hypotheses of which: accounting departments staff of Sudanese universities lack knowledge of the importance of forensic accounting There were many findings for the study some of which were awareness by staff members of Sudanese universities accounting department of the significance of forensic accounting and to incorporate it into accounting curriculum. The most important recommendations were the need to prepare clear and specific plans on how to merge forensic accounting into accounting departments curriculum in Sudanese universities and to encourage the professional boards to accredit forensic accounting as a profession so as to encourage its inclusion in accounting curriculum in Sudanese universities.

\subsection{Commentary on Previous Studies}

From the above is clear there is need to develop the literature the objectives of which were confined to the light on the fundamental aspects of legal support services and forensic expert testimony, and providing proof of the need to include criminology and law science, the legal and organizational environment, and ethics in the forensic accountants teaching curriculum. It stressed the need to work to reflect its importance and role in business law suits. In this, it different from the previous literature with regard to objectives though we agreed with Mohammad (2017) on aims though differed with regard to the population, sample and time period.

\subsection{Research Procedures}

This section examines the analysis of major and personal data and test the hypotheses of the study.

\section{The Methodology}

The researcher adopted the descriptive method because it is appropriate to this kind of study which is defined as set of integrated research procedures for the description of the phenomenon or subject on the basis of the collection data, their classification, data processing, accurate analysis to draw their implications, reach results, and generalizations about the subject or topic under study.

\section{The research population:}

The sampling frame is composed of the entire staff of Accounting departments in universities in the Kingdom of Saudi Arabia in their different positions: Teaching Assistant, lecturer, assistant professor, associate professor and professor. A random sample of 150 staff member was selected from the accounting departments of different universities. A copy of the questionnaire was sent by email. 126 answers were obtained from the sample (84\%).

The following table 1 explain the size and composition of the sample:

Table 1. Showing the size and description of the sample:

\begin{tabular}{|c|c|c|c|}
\hline & Clarification & Frequency & Percentage \% \\
\hline \multicolumn{4}{|l|}{ Gender: } \\
\hline & male & 89 & 71 \\
\hline & female & 37 & 29.4 \\
\hline & Total & 126 & 100 \\
\hline \multicolumn{4}{|l|}{ Age: } \\
\hline & More than 30 less than 40 & 2 & 1.60 \\
\hline & Greater than 40 and less than 50 & 39 & 31 \\
\hline & Greater than 50 & 85 & 67.4 \\
\hline & Total & 126 & 100 \\
\hline \multicolumn{4}{|l|}{ Degree: } \\
\hline & Doctorate & 95 & 76.6 \\
\hline
\end{tabular}




$\begin{array}{rcc}\text { Master } & 25 & 20.2 \\ \text { Bachelor's } & 4 & 3.2 \\ & \mathbf{1 2 4} & \mathbf{1 0 0}\end{array}$

Scientific grade and rank:

$\begin{array}{rcc}\text { Professor } & 3 & 2.4 \\ \text { Co-professor } & 23 & 18.3 \\ \text { Assistant Professor } & 65 & 51.6 \\ \text { Lecturer } & 27 & 21.4 \\ \text { Teaching Assistant } & 8 & 6.3 \\ & \mathbf{1 2 6} & \mathbf{1 0 0}\end{array}$

Years of Experience:

Less than 5 years 17

13.5

More than 5 and Less than 10 years

25

19.8

10 years and less than 15

24

19

Greater than 15

60

47.6

Total

126

100

Source: The researcher prepared from the data of the questionnaire $2021 \mathrm{AD}$

\section{It is clear from Table 1 that:}

$67.4 \%$ of the study sample individuals are over 40 years old and less than 50 years old, $31 \%$ are over 30 years old and less than 40 years old, and the lowest percentage, which is only $1.6 \%$, are less than 30 years old. As well as, $76.6 \%$ hold $\mathrm{PhD}, 20.2 \%$ hold Master, 3.2\% hold Bachelor, 51.6\% are Assistant Professor, 21.4\% are Lecturer, 18.3\% are Associate Professor, 6.3\% are Teaching Assistant, $4.2 \%$ Professor, and $13.5 \%$ with less than 5 years of experience in the field of university teaching, $19.8 \%$ have experience greater than 5 years and less than 10 years, $19 \%$ have experience of 10 years and less than 15 years, $47.6 \%$ have more than 15 years of experience in the field of university teaching.

\section{Research Tools}

To achieve the objectives of the study, the researcher focused on the questionnaire as an information and data collection tool for the research.

\section{Apparent validity:}

To check the apparent validity of the questionnaire it was submitted to 6 experienced referees in accounting for their opinions of its suitability for the objectives for which it was prepared. On basis of their suggestions, some statements were amended and others deleted. In its final form the questionnaire was composed of 3 axes with 17 statements.

Reliability and Validity of the tool (referees authenticity):

The study used a pilot sample consisting of (10) questionnaires to calculate the reliability, and validity of the questionnaire, which was measured by Cronbach's Alpha, and the reliability as shown in the table below:

Table 2. Cronbach's Alpha coefficient:

\begin{tabular}{ccc}
\hline N. of cases & N. of item & Cronbach's Alpha \\
\hline 10 & 17 & 0.75
\end{tabular}

The reliability in the above equals 0.75 , it's high and positive

Validity coefficient $=$ square root of reliability coefficient

Validity coefficient $=\sqrt{\text { reliabilty coefficent }}$

$$
=\sqrt{0.75} \quad=0.75
$$

So, Both the Reliability and the Validity coefficients are high, this indicate that the Instrument was well developed Statistical Treatments. 
The data was entered and processed with SPSS and statistical tools were used for the analysis and primary Data which were processed for frequencies, descriptive tables and graphs, arithmetic mean, standard deviation and the coding of respondents answers for computer statistical data entry as follows.

Table 3. Showing numerical representation of descriptive variables:

\begin{tabular}{cccccc}
\hline Statement & Strongly disagree & Disagree & Not-sure & Agree & Strongly agree \\
\hline Number & 1 & 2 & 3 & 4 & 5 \\
\hline
\end{tabular}

The measures used in the research has been corrected as follows:

The scale total value is the sum of all individual statements values:

$(1+2+3+4+5) / 5=5$

Table 4. The likely means as in the following table:

\begin{tabular}{cccccc}
\hline Option & Strongly agree & \multicolumn{1}{c}{ Agree } & Not-sure & Disagree & Strongly disagree \\
\hline Weigh & 5 & 4 & 3 & 2 & 1 \\
Mean & $4.2-5$ & $3.4-4.19$ & $2.6-3.39$ & $1.8-2.59$ & $1-1.79$ \\
\hline
\end{tabular}

Cronbach's Alpha test:

The test was used to measure the internal consistency of the research statement to check the validity of the tool. The test is considered good and suitable if the Alpha Cronbach's value exceed 60\%.

\section{One sample test:}

Presentation and discussion of hypothesis and results:

In order to check the validity of the sample the researchers used (T) test for one sample, arithmetic averages and standard deviation and ranking.

\section{Presentation and discussion of results related to first hypothesis:}

H1: "There is no knowledge of the importance of forensic accounting among accounting department staff of Kingdom of Saudi Arabia universities"

Table 5. T test for one sample, arithmetic mean, standard deviation and rank for statements of $1^{\text {st }}$ hypothesis:

\begin{tabular}{|c|c|c|c|c|c|c|c|c|}
\hline Statement & $\begin{array}{l}\text { Arithmeti } \\
\text { c mean }\end{array}$ & $\begin{array}{l}\text { Standard } \\
\text { deviation }\end{array}$ & Rank & $\begin{array}{c}\text { One } \\
\text { sample } \\
\text { T-test (3) }\end{array}$ & Df & p-value & $\begin{array}{l}\text { Interpreta } \\
\text { tion }\end{array}$ & Result \\
\hline \multicolumn{9}{|c|}{ I have a strong conviction of the importance of forensic accounting for business. } \\
\hline Q1 & 4.714 & 0.519 & 1 & 101.9 & 125 & 0.00 & Significant & $\begin{array}{l}\text { Strongly } \\
\text { agree }\end{array}$ \\
\hline \multirow[t]{2}{*}{ Q2 } & \multicolumn{8}{|c|}{$\begin{array}{l}\text { In light of accelerating development in field of business the recourse to forensic accountant to } \\
\text { detect, deter and protect against fraud and financial and administrative corruption is } \\
\text { important and a necessity. }\end{array}$} \\
\hline & 4.48 & 0.678 & 2 & 74.234 & 125 & 0.00 & Significant & $\begin{array}{c}\text { Strongly } \\
\text { agree }\end{array}$ \\
\hline \multirow[t]{2}{*}{ Q3 } & \multicolumn{8}{|c|}{$\begin{array}{l}\text { The reliance on forensic accountants in evaluation of businesses for legal purposes such as } \\
\text { shareholders discounts or the liquidation of the company or any other purposes achieves more } \\
\text { effectiveness and better performance. }\end{array}$} \\
\hline & 4.412 & 0.648 & 3 & 76.401 & 125 & 0.00 & Significant & $\begin{array}{c}\text { Strongly } \\
\text { agree }\end{array}$ \\
\hline \multirow[t]{2}{*}{ Q4 } & \multicolumn{8}{|c|}{$\begin{array}{l}\text { In your opinion when there are financial disputes between different parties, the forensic } \\
\text { accountant settles them by providing an optimum solution to all parties. }\end{array}$} \\
\hline & 4.087 & 0.829 & 6 & 56.3 & 125 & 0.00 & Significant & Agree \\
\hline Q5 & \multicolumn{8}{|c|}{$\begin{array}{l}\text { The use of forensic accountants for investigation and for legal consultation in the field of } \\
\text { business helps better prosecute the perpetrators of fraud and other financial crimes. }\end{array}$} \\
\hline
\end{tabular}




$\begin{array}{llllllll}4.214 & 0.785 & 4 & 60.189 & 125 & 0.00 & \text { Significant } & \begin{array}{c}\text { Strongly } \\ \text { agree }\end{array}\end{array}$

Q6

The use by companies of forensic accountants when conducting internal investigations of financial crimes lead to their discovery (if any) and corrects any defects in internal monitoring and control systems.

$\begin{array}{llllllll}4.182 & 0.833 & 5 & 56.34 & 125 & 0.00 & \text { Significant } & \text { Agree }\end{array}$

$\begin{array}{llll}\text { Average } & 4.348 & 0.715 & \begin{array}{c}\text { Strongly } \\ \text { agree }\end{array}\end{array}$

Source: The researcher prepared from the data of the questionnaire $2021 \mathrm{AD}$

\section{It is clear from Table 5 that:}

All statements are statistically significant at the level of significance 0.01 , and all of them have the degree of approval. The most important statement of the first hypothesis statements is (I have a very high conviction of the importance of the role of the forensic accounting in the field of business) with an arithmetic average of (4.714) and a standard deviation of (0.519), and the least important statement is (in your opinion, when there are financial disputes between different parties, the forensic accountant settles them and provides an optimal solution for all parties) with an arithmetic average of (4.087) and a standard deviation of (0.829). The standard deviation of the axis is (0.715), which indicates the concentration of the values around its arithmetic mean. The overall average for the axis is (4.348). Therefore, we conclude that the faculty members in accounting departments in universities in the Kingdom of Saudi Arabia are aware of the importance of the forensic accounting.

\section{Presentation and discussion of results of Second hypothesis:}

H2: "There is no need among staff members of Kingdom of Saudi Arabia universities accounting department staff for the inclusion of forensic accounting in accounting teaching curriculum".

Table 6. T test for one sample, arithmetic mean, standard deviation and rank for statements of $2^{\text {nd }}$ hypothesis:

\begin{tabular}{|c|c|c|c|c|c|c|c|c|}
\hline Statement & $\begin{array}{l}\text { Arith } \\
\text { metic } \\
\text { mean }\end{array}$ & $\begin{array}{l}\text { Standard } \\
\text { deviation }\end{array}$ & Rank & $\begin{array}{c}\text { One } \\
\text { sample } \\
\text { T-test (3) }\end{array}$ & Df & p-value & $\begin{array}{l}\text { Interpretat } \\
\text { ion }\end{array}$ & Result \\
\hline \multirow[t]{2}{*}{ Q1 } & \multicolumn{8}{|c|}{$\begin{array}{l}\text { Forensic accounting include knowledge of law, criminology, psychology, communication and } \\
\text { information technology and all these sciences together are not found in any one accounting } \\
\text { science department. }\end{array}$} \\
\hline & 4.096 & 0.936 & 5 & 48.878 & 124 & 0.00 & Significant & Agree \\
\hline \multirow{2}{*}{ Q2 } & \multicolumn{8}{|c|}{$\begin{array}{l}\text { Forensic accounting is considered complementary to auditing but not part of it for the forensic } \\
\text { accountant begins where the auditor ends. }\end{array}$} \\
\hline & 4.288 & 0.716 & 3 & 66.824 & 124 & 0.00 & Significant & $\begin{array}{l}\text { Strongl } \\
\text { y agree }\end{array}$ \\
\hline \multirow[t]{2}{*}{ Q3 } & \multicolumn{8}{|c|}{$\begin{array}{l}\text { The auditing and other shortcomings could be overcome by merging forensic accounting as } \\
\text { part of accounting subjects in the departments of accounting in Kingdom of Saudi Arabia } \\
\text { universities so as to graduate qualified forensic accountants Qualified in different fields such } \\
\text { as fraud examiners, financial crimes in a way that respond to increasing needs of business. }\end{array}$} \\
\hline & 4.584 & 0.51 & 3 & 100.312 & 124 & 0.00 & Significant & $\begin{array}{l}\text { Strongl } \\
\text { y agree }\end{array}$ \\
\hline \multirow[t]{2}{*}{ Q4 } & \multicolumn{8}{|c|}{$\begin{array}{l}\text { The inability of accounting departments in Kingdom of Saudi Arabia university to include } \\
\text { forensic accounting in tis curriculum increases corrupt financial and administrative practices } \\
\text { in companies. }\end{array}$} \\
\hline & 3.754 & 0.985 & 6 & 42.763 & 125 & 0.00 & Significant & Agree \\
\hline Q5 & \multicolumn{8}{|c|}{$\begin{array}{l}\text { It is necessary to find a method to merge forensic accounting in accounting curriculum in } \\
\text { Kingdom of Saudi Arabia universities accounting departments such as creating a } \\
\text { sub-department within the department of accounting to teach the sciences and skills of forensic } \\
\text { accounting. }\end{array}$} \\
\hline
\end{tabular}




$\begin{array}{llllllll}4.187 & 0.833 & 4 & 55.731 & 122 & 0.00 & \text { Significant } & \text { Agree }\end{array}$

There is a need to prepare complementary graduate program educational programs for a number of classes in forensic accounting and for those who wish to learn the subject and Q6 acquire forensic accounting skills.

$\begin{array}{llllllll}4.349 & 0.684 & 2 & 71.281 & 125 & 0.00 & \text { Significant } & \begin{array}{l}\text { Strongl } \\ \mathbf{y} \text { agree }\end{array}\end{array}$

$\begin{array}{llll}\text { Average } & 4.209 & 0.777 & \text { Strongl }\end{array}$

y agree

Source: The researcher prepared from the data of the questionnaire $2021 \mathrm{AD}$

\section{It is clear from Table 6 that:}

All statements are statistically significant at the level of significance 0.01 , and all of them have the degree of approval. The most important statement of the second hypothesis statements is (deficiencies in auditing accounts and others can be overcome by integrating forensic accounting within the accounting curricula in accounting departments at universities in the Kingdom of Saudi Arabia in order to prepare qualified forensic accountants in several areas; such as examining fraud and financial crimes in a way that responds to the changes and increasing needs in the field of business) with an arithmetic average of (4.584) and a standard deviation of (0.510). The least important statement is (the failure of the accounting departments at universities in the Kingdom of Saudi Arabia to include the forensic accounting curriculum in its curricula increases the practices of financial and administrative corruption in companies) with an arithmetic average of (3.754) and a standard deviation of (0.985). The standard deviation of the axis reached (0.777), which indicates the concentration of the values around its arithmetic mean. The overall average of the axis is (4.209). Therefore, we conclude that the faculty members in accounting departments at universities in the Kingdom of Saudi Arabia need to include the forensic accounting in the educational curricula.

\section{Presentation and discussion of the result related to the third hypothesis:}

H3: "There are no constraints from academic staff perspective of the department of accounting in Kingdom of Saudi Arabia universities preventing the inclusion of forensic accounting in the curriculum".

Table 7. $\mathrm{T}$ test for one sample, arithmetic mean, standard deviation and rank for statements of $3^{\text {rd }}$ hypothesis

\begin{tabular}{|c|c|c|c|c|c|c|c|c|}
\hline Statement & $\begin{array}{l}\text { Arithmeti } \\
\text { c mean }\end{array}$ & $\begin{array}{l}\text { Standard } \\
\text { deviation }\end{array}$ & Rank & $\begin{array}{c}\text { One } \\
\text { sample } \\
\text { T-test (3) }\end{array}$ & Df & $\begin{array}{c}\text { p-valu } \\
\text { e }\end{array}$ & $\begin{array}{l}\text { Interpretati } \\
\text { on }\end{array}$ & Result \\
\hline \multirow[t]{2}{*}{ Q1 } & \multicolumn{8}{|c|}{$\begin{array}{l}\text { The university administration is not convinced of the value and feasibility of inclusion of } \\
\text { forensic accounting in Kingdom of Saudi Arabia universities accounting departments } \\
\text { curriculum. }\end{array}$} \\
\hline & 2.976 & 0.983 & 4 & 33.965 & 125 & 0.00 & Significant & Not sure \\
\hline \multirow[t]{2}{*}{ Q2 } & \multicolumn{8}{|c|}{$\begin{array}{l}\text { There is a lack of specific plan on how to merge forensic accounting in the accounting } \\
\text { curricula in department of accounting in Kingdom of Saudi Arabia universities. }\end{array}$} \\
\hline & 3.817 & 0.991 & 1 & 43.233 & 125 & 0.00 & Significant & Agree \\
\hline \multirow[t]{2}{*}{ Q3 } & \multicolumn{8}{|c|}{$\begin{array}{l}\text { There are no qualified and trained human frames (staff members) that could teach forensic } \\
\text { accounting in the departments of accounting in Kingdom of Saudi Arabia universities. }\end{array}$} \\
\hline & 3.055 & 1.097 & 3 & 31.247 & 125 & 0.00 & Significant & Not sure \\
\hline \multirow[t]{2}{*}{ Q4 } & \multicolumn{8}{|c|}{$\begin{array}{l}\text { The costs are excessively high for the inclusion of forensic accounting in Accounting } \\
\text { departments curriculum in Kingdom of Saudi Arabia universities. }\end{array}$} \\
\hline & 2.642 & 1.141 & 5 & 25.985 & 125 & 0.00 & Significant & Not sure \\
\hline \multirow[t]{2}{*}{ Q5 } & \multicolumn{8}{|c|}{$\begin{array}{l}\text { Forensic accounting has not been approved by professional societies in Sudan which the } \\
\text { reason for its non-inclusion in Kingdom of Saudi Arabia universities accounting curriculum. }\end{array}$} \\
\hline & 3.563 & 0.764 & 2 & 52.345 & 125 & 0.00 & Significant & Agree \\
\hline Average & 3.21 & 0.995 & & & & & & Not sure \\
\hline
\end{tabular}

Source: The researcher prepared from the data of the questionnaire 2021 AD 


\section{It is clear from Table 7 that:}

The majority of the statements are statistically significant at a level of significance 0.01 , and the majority of the sample' individuals did not express specific opinions about it. The most important statement of the third hypothesis statements is (there are no clear and specific plans for how to integrate the forensic accounting into the accounting curricula in accounting departments at universities in the Kingdom of Saudi Arabia) with an arithmetic average of (3.817) and a standard deviation of (0.991). The least important statement is (the costs are very large when forensic accounting is included in the accounting curricula in accounting departments at universities in the Kingdom of Saudi Arabia and these departments cannot provide the costs) with an arithmetic average of (2.642) and a standard deviation of (1.141). The standard deviation of the axis reached (0.995), which indicates the concentration of the values around its arithmetic mean. The overall average of the axis is (3.210). Therefore, we conclude that the faculty members in the accounting departments of universities in the Kingdom of Saudi Arabia do not give specific opinions about the existence of difficulties that prevent the inclusion of the forensic accounting in the curricula of accounting education.

\section{Research Results}

This research reached the following results:

- All faculty members in accounting departments at universities in the Kingdom of Saudi Arabia are aware of the importance of the forensic accounting.

In the field of business, it is necessary to seek the assistance of the forensic accountant to discover and prevent financial fraud and corruption.

It is possible to overcome the deficiencies in auditing and other fields by integrating the forensic accounting within the accounting curricula in accounting departments at the universities in the Kingdom of Saudi Arabia.

The forensic accounting is complementary to the audit and not part of it; as the forensic accountant starts from where the auditor ends.

There are no clear and specific plans for how to include the forensic accounting in the accounting departments at the universities in the Kingdom of Saudi Arabia

There are no large costs that prevent the inclusion of the forensic accounting within accounting curricula in the accounting departments at the universities in the Kingdom of Saudi Arabia.

\section{Research Recommendations}

In light of the results obtained, the research recommends the following:

There is a great need to include the curriculum of the forensic accounting in accounting departments at the universities in the Kingdom of Saudi Arabia.

Establish specific and clear plans for how to include the forensic accounting in the accounting departments at the universities in the Kingdom of Saudi Arabia.

It is preferable for companies to seek the assistance of a forensic accountant when carrying out internal investigations regarding the financial crimes.

Increase the qualification and training of the faculty members in accounting departments at the universities in the Kingdom of Saudi Arabia in the field of forensic accounting.

Conduct more (conferences, research, training courses, workshops, ....) by the accounting departments in universities in the Kingdom of Saudi Arabia and the bodies organizing the accounting profession in the field of forensic accounting in order to demonstrate its importance further.

The university administration shall bear any costs that may result from the inclusion of the forensic accounting in the accounting curricula in the accounting departments at the universities in the Kingdom of Saudi Arabia.

\section{References}

Al-Saad (2012). Saleh Abdulrahman, "Forensic Accounting in Saudi Arabia: Current Practice and Future": An Empirical Study, King Abdulaziz University Journal, Economics and Administration, Volume 27, First Issue, 3-94, 2012. https://doi.org/10.4197/Eco.27-1.1

Bourgl, (2015). Leana, "The Role Of Forensic Accounting And Corporate Governance And The Complementary Relationship Between ThCm To Face Financial And Administrative Corruption In The Jordanian Public 
Shareholding Companies", Master Thesis, CB, Accounting Department, Middle East University, 2015.

Cumber (2014). Jamila Said, "Measuring the extent of awareness of the importance of Forensic accounting and the need to integrate it in the curricula of higher education among faculty members of accounting departments in Libyan universities", Journal of the University - Volume XVI - Volume I - February 2014.

Curtis, George E. (2008). "Legal and Regulatory Environments and Ethics: Essential Components of Fraud and Forensic Accounting Curriculum", Issues in Accounting Education, Vol 23, No 4, 535-543. https://doi.org/10.2308/iace.2008.23.4.535

Elzain (2019). Elzain ALamin, "Measurement of the knowledge of Sudanese universities departments of accounting staff of the importance of forensic accounting and its inclusion in accounting curricula", International Journal of Recent Scientific Research, Vol. 10, Issue, 12(A), 36262-36267, December, 2019.

Mohammed (2017). Abdul Wahab Musa, "The feasibility of the inclusion of Forensic accounting within the curricula of accounting departments in Sudanese universities", Journal of Administrative Sciences and Economic Science, University of West Kordofan, the second issue 2017, 58-85.

Mohammed Noor (2018). Musa, "Forensic accounting and its role in reducing financial and administrative corruption", (Sudan: Khartoum, unpublished doctoral thesis, Department of Accounting, College of Business Studies, Sudan University of Science and Technology, 2018).

Mustafa Abu Amara \& Ahmed Al-Harkan (2019). "Evaluating the Adequacy of the Current Content of Forensic Accounting in the Accounting Programs in Saudi Universities", Global Journal of Economics and Business e-ISSN 2519-9293, p-ISSN 2519-9285 Vol. 6, No. 3, 2019, 385- 406.

Singleton, T. W., \& Singleton, A. J. (2010). "Fraud Auditing and Forensic Accounting", (4th Ed,) New York: Wiley \& Sons, Inc. (AICPA, 2005), Forensic and Litigation Services Committee Developed the Definition. https://doi.org/10.1002/9781118269183

Wadhwa, Lalit \& Pal, Virender (2012). "Forensic Accounting And Fraud Examination In India", International Journal of Applied Engineering Research, V. 7, N. 11. http://www.mohe.gov.sd/index.php/ar/, https://www.alwatan.com.sa/article/37767

\section{Copyrights}

Copyright for this article is retained by the author(s), with first publication rights granted to the journal.

This is an open-access article distributed under the terms and conditions of the Creative Commons Attribution license (http://creativecommons.org/licenses/by/4.0/). 